\title{
Identifikasi Protein Adhesi Pili Proteus Mirabilis P355 dan Protein Reseptor pada Vesika Urinaria Kelinci
}

\author{
Diana Chusna Mufida ${ }^{1^{*}}$, Sumarno $^{2}$, Sanarto Santoso ${ }^{3}$ \\ ${ }^{1}$ Program Studi Pendidikan Dokter, Fakultas Kedokteran, Universitas Negeri Jember, Jember \\ ${ }^{2}$ Laboratorium Biomedik Fakultas Kedokteran Universitas Brawijaya, Malang \\ ${ }^{3}$ Laboratorium Mikrobiologi Fakultas Kedokteran Universitas Brawijaya, Malang
}

\begin{abstract}
Abstrak
Infeksi saluran kemih (ISK) merupakan infeksi nosokomial yang sering terjadi di rumah sakit. Penyebab ISK nosokomial ini diantaranya adalah Proteus mirabilis p355 dan sering dijumpai pada pasien yang memakai kateter. Proteus mirabilis mempunyai berbagai macam faktor virulensi, diantaranya adalah fimbria atau pili. Tujuan penelitian ini untuk mengidentifikasi protein pili Proteus mirabilis (molekul adhesin) serta mencari protein reseptor bakteri tersebut pada epitel vesika urinaria kelinci. Penelitian ini dilakukan dengan isolasi protein pili, selanjutnya dilakukan uji hemaglutinasi dan uji hambat adhesi. Uji hambat adhesi mempergunakan protein pili yang telah dielektroelusi dan didialisa, disalutkan pada sel epitel vesika urinaria kelinci dengan dosis $400 \mu \mathrm{l}, 200 \mu \mathrm{l}, 100 \mu \mathrm{l}, 50 \mu \mathrm{l}, 25 \mu \mathrm{l}, 12,5 \mu \mathrm{l}$ dan $0 \mu \mathrm{l}$ sebagai kontrol. Selanjutnya dilakukan identifikasi protein reseptor dengan cara menyalut bakteri Proteus mirabilis dengan matriks ekstra seluler dari epitel vesika urinaria kelinci. Hasil penelitian ini menunjukkan adanya reaksi hemaglutinasi dari protein pili dengan berat 35,2 kDa dengan titer tertinggi 1/521. Hasil uji hambat adhesi epitel vesika urinaria yang disalut protein pili dengan berat 35,2 kDa menunjukkan bahwa semakin tinggi dosis protein yang diberikan, semakin sedikit bakteri yang melekat pada epitel vesika urinaria. Penurunan ini terjadi secara signifikan dengan indeks regresi $(r)=0,95$ dan $p$-value $=0,00$. Berdasarkan penelitian ini dapat disimpulkan bahwa protein pili Proteus mirabilis dengan berat molekul 35,2 kDa merupakan protein adhesin, sedangkan protein reseptor Proteus mirabilis diprediksi mempunyai berat molekul, $36 \mathrm{kDa}, 24,5 \mathrm{kDa}$ dan $24 \mathrm{kDa}$.
\end{abstract}

Kata kunci : adhesi, pili, protein reseptor, Proteus mirabilis

\section{PENDAHULUAN}

Infeksi saluran kemih (ISK) merupakan penyakit yang sering didiagnosa pada pasien yang pulang dari rumah sakit dan merupakan infeksi nosokomial yang sering terjadi. Menurut National Nosocomial Infection Surveillance (NNIS), jumlah penderita ISK sekitar 35\% dari seluruh infeksi nosokomial [1]. Tingkat infeksi saluran kemih yang tinggi karena infeksi nosokomial berhubungan dengan pemakaian kateter (indwelling catheter). Pemakaian kateter ini dapat menyebabkan bakteriuria yang asimtomatik dan selanjutnya dapat menyebabkan bakteremia lebih dari 5\% [1]. Studi yang dilakukan oleh Daifiku dan Stamm, menunjukkan bahwa pada pasien yang memakai kateter adhesi Proteus mirabilis ke sel vesika urinaria mengalami peningkatan [2].

Proteus mirabilis termasuk dalam tribe Proteae, famili Enterobacteriae. Bakteri ini merupakan salah satu Gram negatif penyebab

\footnotetext{
* Alamat korespondensi penulis:

Diana Chusna

e-mail : chusna_diana@yahoo.com

Alamat : Jl. Kalimantan 37 Jember, Jawa Timur, 68121
}

terbanyak infeksi saluran kemih. Infeksi saluran kemih yang disebabkan Proteus mirabilis bersifat persisten, sulit diterapi dan dapat berakibat fatal. Bakteri ini dapat menimbulkan komplikasi antara lain pyelonephritis akut dan kronik, cystitis, pembentukan batu di ginjal dan vesika urinaria [3]. Proteus mirabilis mempunyai beberapa faktor virulensi, yaitu fimbria atau pili, hemolisin, flagella, immunoglobulin A protease deaminase serta urease [3].

Proses infeksi mikroorganisme dapat melalui beberapa tahap, yaitu dimulai dengan pelekatan atau adhesi pada permukaan sel inang, dan selanjutnya dapat terjadi invasi dan menyebar secara lokal atau sistemik. Molekul adhesi (perantara pelekatan bakteri ke inang) pada bakteri bisa terletak di pili atau di outer membrane protein (OMP). Pelekatan bakteri ke sel inang ini bersifat spesifik [4].

Molekul adhesi pada setiap bakteri mempunyai berat molekul yang berbeda-beda. Sumarno, berhasil mengisolasi molekul adhesi pili $V$. cholera dengan berat molekul $38 \mathrm{kDa}$ dan dari OMP dengan berat molekul $76 \mathrm{kDa}$ [5].

Reseptor dari sel inang pada umumnya merupakan residu dari karbohidrat yaitu gliko- 
protein atau glikolipid. Sumarno, menemukan molekul reseptor Vibrio cholera pada enterosit tikus putih mempunyai berat molekul $62 \mathrm{kDa}$, 28,9 kDa, 13,5 kDa, 12,7 kDa dan $10 \mathrm{kDa}$ [5]. Berdasarkan uraian diatas, maka penelitian ini bertujuan untuk mengidentifikasi protein pili Proteus mirabilis (molekul adhesin) serta mencari protein reseptor bakteri tersebut pada epitel vesika urinaria kelinci.

\section{METODE PENELITIAN}

\section{Metode kultur Proteus mirabilis}

Bakteri yang dipergunakan adalah Proteus mirabilis galur lokal yang berasal dari urin pasien bakteriuria. Bakteri ini diisolasi menu-rut metode Ehara [6]. Berdasarkan metode ini, bakteri dibiakkan pada media media TCG yang memperkaya pertumbuhan pili Proteus mirabilis. Media ini megandung 0,02\% thioproline, 0,3\% $\mathrm{NaHCO}_{3}, 0,15$ bactotrytonr, 0,2\% yeast extract, $0,5 \% \mathrm{NaCl}, 2 \%$ bacto agar dan $1 \mathrm{mM}$ EGTA. Media agar dibuat dalam botol berkapasitas 250 $\mathrm{ml}$ secara miring sebanyak $50 \mathrm{ml}$ agar. Proteus mirabilis yang dipilih ditanam pada media Brain Heart Infusion (BHI) yang dieramkan pada suhu $37{ }^{\circ} \mathrm{C}$ selama empat jam. Kemudian suspensi bakteri sebanyak $10 \mathrm{ml}$ dimasukkan ke dalam setiap botol yang mengandung media TCG. Selanjutnya dilakukan pengeraman pada suhu $37{ }^{\circ} \mathrm{C}$ selama 48 jam.

\section{Metode Isolasi Pili Proteus mirabilis}

Pili dipanen dari 50 botol biakan bakteri. Hasil koleksi bakteri ditambahkan Trichloro Acetic Acid (TCA) sampai konsentrasi 3\%. Setelah dikocok rata kemudian diletakkan pada suhu kamar selama satu jam dan setiap 15 menit dikocok. Selanjutnya dilakukan sentrifugasi $6000 \mathrm{rpm}$ selama 10 menit pada suhu $4{ }^{\circ} \mathrm{C}$. Pelet diambil dan diresuspensi dengan cairan PBS pH 7,4 dengan perbandingan 1:10. Bakteri dicukur dengan menggunakan mixer buatan sendiri. Bakteri dicukur dengan kecepatan penuh selama satu menit, diulang sampai lima kali dengan masa istirahat satu menit. Hasil pencukuran tersebut dilakukan sentrifugasi selama 30 menit dengan kecepatan $12000 \mathrm{rpm}$ suhu $4{ }^{\circ} \mathrm{C}$. Pili yang terletak dibagian atas diambil, endapan disuspensi dengan larutan dan cara yang sama kemudian dikumpulkan dengan cara mencukur ulang beberapa kali, sampai dihasilkan supernatan yang menunjukkan tes aglutinasi negatif.

Sodium Dodecyl Sulfate Polyacrilamide Gel Electroforesis (SDS-PAGE)

Monitoring berat molekul dikerjakan menggunakan SDS-PAGE metode Laemli [7]. Sampel protein dipanaskan pada suhu $100{ }^{\circ} \mathrm{C}$ selama lima menit dalam larutan penyangga yang mengandung $5 \mathrm{mM}$ Tris $\mathrm{HCl}$ pH 6,8, 2-mercapto ethanol $5 \%$, sodium dodecyl sulfate $2,5 \%$, gliserol $10 \%$ dengan warna pelacak bromophenol blue. Dipergunakan mini slab gel $12,5 \%$ dengan stacking gel 4\%. Voltase yang digunakan $125 \mathrm{mV}$. Bahan yang digunakan adalah coomasive brilliant blue dan molekul standar Sigma low range marker.

Metode Pemurnian Protein Hemaglutinin Pili Proteus mirabilis

Metode yang dilakukan seperti yang telah dikerjakan oleh Ehara dengan modifikasi Sumarno [5]. Gel hasil SDS-PAGE dari pili hasil koleksi, dipotong lurus pada berat molekul yang diinginkan dan potongan pita tersebut dikumpulkan kemudian dimasukkan ke dalam membran dialisa memakai cairan penyangga elektroforesis, yaitu running buffer. Selanjutnya dilakukan elektroelusi dengan menggunakan elektroforesis ontal apparatus aliran $125 \mathrm{mV}$ selama 25 menit. Hasil elektroforesis didialisa dengan cairan penyangga PBS $\mathrm{pH} 7,4$ selama 2 kali 24 jam masing-masing 1 liter dan diganti dua kali. Cairan dialisa tersebut selanjutnya diuji hemaglutinasi.

\section{Metode Uji Hemaglutinasi}

Uji hemaglutinasi dikerjakan menurut petunjuk dari Li, et al. [9]. Pengenceran sampel dibuat konsentrasi $1 / 2$ pada mikroplat $V$, tiap sumur volumenya $50 \mu \mathrm{l}$. Ditambahkan suspensi darah merah mencit konsentrasi $0,5 \%$ dengan volume sama pada setiap sumur mikroplat V. Kemudian digoyang dengan rotator plate selama satu menit. Selanjutnya diletakkan dalam suhu kamar selama satu jam. Besar titer ditentukan dengan pengamatan aglutinasi darah merah pada pengenceran yang terendah. Sampel yang diuji adalah crude pili dan protein pili Proteus mirabilis. Darah yang dipakai adalah darah mencit dan darah manusia.

\section{Isolasi Sel Epitel Vesika Urinaria Kelinci}

Kelinci yang dipergunakan adalah kelinci sehat dengan berat badan 1,5 kg. Kelinci dianestesi dengan menggunakan kloroform, kemudian diambil bagian vesika urinaria. Vesika urinaria dipotong dan dibuka. Vesika urinaria dicuci dengan PBS $\mathrm{pH}$ 7,4 yang mengandung $1 \mathrm{mM}$ dithiothretiol pada suhu $4{ }^{\circ} \mathrm{C}$ sampai bersih. Setelah itu, vesika urinaria dimasukkan ke dalam cairan yang mengandung 1,5 $\mathrm{mM} \mathrm{KCl}, 9,6$ $\mathrm{mM} \mathrm{NaCl}, 27 \mathrm{mM} \mathrm{Na}$ Citrat, $8 \mathrm{mM} \mathrm{KH}_{2} \mathrm{SO}_{4}$ dan 5,6 $\mathrm{mM} \mathrm{Na} \mathrm{NPO}_{4}$ dengan $\mathrm{pH}$ 7,4. Jaringan diinkubasi pada shaking incubator selama 15 menit, dengan suhu $37{ }^{\circ} \mathrm{C}$. Supernatan dibuang 
dan jaringan dipindahkan dalam cairan yang mengandung 1,5 mM EDTA dan 0,5 mM dithiothretiol, digojok kuat selama 15 menit pada suhu $37{ }^{\circ} \mathrm{C}$, kemudian supernatan dibuang. Jaringan dicuci dengan PBS dan disentrifugasi selama 5 menit dengan kecepatan 1000 rpm, tahap ini diulang sebanyak tiga kali. Sel Epitel vesika urinaria diisolasi dengan melakukan suspensi pada jaringan dengan menggunakan PBS steril. Selanjutnya dilakukan penghitungan sel epitel vesika urinaria dengan spektrofotometer dengan panjang gelombang $560 \mathrm{~nm}$ sampai konsentrasi $10^{6} \mathrm{ml}^{-1}$. Epitel vesika urinaria ini kemudian dipergunakan untuk uji adhesi, uji hambat adhesi dan diambil bagian ECM.

Uji Adhesi

Uji adhesi dilakukan menurut modifikasi Nagayama et al. [8]. Bakteri Proteus mirabilis dibiakkan dalam media laktosa broth pada suhu $37^{\circ} \mathrm{C}$. Selanjutnya bakteri dipanen dengan menggunakan sentrifugasi dengan kecepatan 6000 rpm selama 10 menit pada suhu $4{ }^{\circ} \mathrm{C}$. Endapan disuspensi dengan PBS. Kandungan bakteri dibuat $10^{8} \mathrm{ml}^{-1}$ menggunakan spektrofotometer pada panjang gelombang $600 \mathrm{~nm}$. Diambil $1 \mathrm{ml}$ bakteri dan $1 \mathrm{ml}$ sel epitel vesika urinaria kemudian dihomogenasi. Homogenat diinkubasi pada shaking waterbath dengan goyangan pelan selama 30 menit pada suhu $37{ }^{\circ} \mathrm{C}$. Dilakukan sentrifugasi pada campuran bakteri dan epitel vesika urinaria tersebut sebanyak dua kali dengan rotasi $1000 \mathrm{rpm}$ masing-masing selama lima menit. Suspensi diambil sebanyak $10 \mu \mathrm{l}$ dengan dua kali ulangan dan dilakukan preparasi dan pewarnaan Gram serta dilanjutkan penghitungan indeks adhesi pada pengamatan dengan mikroskop.

\section{Matrik Ekstra Seluler Epitel Vesika Urinaria}

Metode isolasi matrik ekstra seluler epitel vesika urinaria yang dipakai merujuk pada Sumarno. Epitel vesika urinaria dicuci dengan PBS steril sebanyak tiga kali dan ditambahkan NOG 0,05\% sebanyak $2 \mathrm{ml}$ kemudian dihomogenasi selama satu menit. Kemudian dilakukan sentrifugasi $6000 \mathrm{rpm}$ selama 15 menit pada suhu $4{ }^{\circ} \mathrm{C}$. Supernatan hasil sentrifugasi diambil dan dilakukan dialisa selama 2 kali 24 jam dengan PBS steril. Profil protein hasil isolasi ditentukan dengan metode SDS-PAGE [5].

\section{Uji Protein Reseptor}

Cara yang dipakai seperti pada penelitian Sumarno [5]. Sel bakteri dikultur sehingga konsentrasi mencapai $10^{8} \mathrm{ml}^{-1}$. Selanjutnya $1 \mathrm{ml}$ bakteri dicuci dengan PBS pH 7,4 dengan sentrifugasi kecepatan $6000 \mathrm{rpm}$ selama lima menit pada suhu $4{ }^{\circ} \mathrm{C}$. Endapan disuspensikan dengan suspensi protein MES vesika urinaria. Dilakukan inkubasi dalam water bath dengan suhu $37{ }^{\circ} \mathrm{C}$ dengan goyangan sedang selama 30 menit. Kemudian dilakukan sentrifugasi dengan kecepatan $6000 \mathrm{rpm}$ selama lima menit pada suhu $4{ }^{\circ} \mathrm{C}$. Endapan dipisahkan dari supernatan kemudian disuspensi dengan PBS pH 7,4 volume $1 \mathrm{ml}$. Dilakukan SDS-PAGE untuk supernatan dan suspensi endapan. Sebagai kontrol dipakai suspensi Proteus mirabilis dan protein MES epitel vesika urinaria. Selanjutnya dilakukan analisis untuk mengetahui protein yang berperan sebagai reseptor.

\section{Pengecatan Gram}

Sediaan dari uji adhesi dan uji hambat adhesi pada kaca benda difiksasi. Kemudian preparat dituangi dengan kristal violet selama satu menit, sisa cat dibuang dan dibilas dengan air. Selanjutnya dituangi lugol selama satu menit, sisa cat dibuang dan dibilas dengan air. Preparat dituangi alkohol 96\% selama 5-10 detik atau sampai cat luntur, kemudian dibilas dengan air. Sampel ditetesi dengan safranin selama 30 detik kemudian dibilas dengan air. Sampel dikeringkan, selanjutnya diamati dengan mikroskop dengan pembesaran 100 kali.

\section{Teknik Analisis Data}

Data dianalisis menggunakan uji statistik satu jalur (oneway ANOVA).

\section{HASIL DAN PEMBAHASAN}

Berdasarkan hasil uji hemaglutinasi potongan pili bakteri Proteus mirabilis (Tabel 1), menunjukkan bahwa pada potongan pili ke-2 menunjukkan titer tertinggi yaitu $1 / 16$. Selanjutnya potongan pili dilakukan SDS-PAGE untuk memprediksi berat molekul protein, dengan hasil seperti pada Gambar 1. Profil protein pada SDS-PAGE dari beberapa potongan pili Proteus mirabilis (Gambar 1) menunjukkan protein yang menonjol yaitu protein dengan berat molekul 35,21 kDa, 27,9 kDa, 24 kDa dan 22 kDa.

Tabel 1. Uji hemaglutinasi pili Proteus mirabilis pada eritrosit mencit

\begin{tabular}{lllllllllll}
\hline \multirow{2}{*}{ Materi } & \multicolumn{10}{c}{ Sumur } \\
\cline { 2 - 10 } & 1 & 2 & 3 & 4 & 5 & 6 & 7 & 8 & 9 & 10 \\
\hline P1 & + & + & - & - & - & - & - & - & - & - \\
P2 & + & + & + & - & - & - & - & - & - & - \\
P3 & + & - & - & - & - & - & - & - & - & - \\
P4 & - & - & - & - & - & - & - & - & - & - \\
\hline
\end{tabular}

Selanjutnya protein yang menonjol dipotong dan dilakukan elektroelusi dan dialisa, sehingga 
diperoleh protein larutan. Hasil elektroelusi dan dialisa protein pili tersebut selanjutnya diuji hemaglutinasi pada eritrosit mencit, dengan hasil seperti pada Tabel 2.

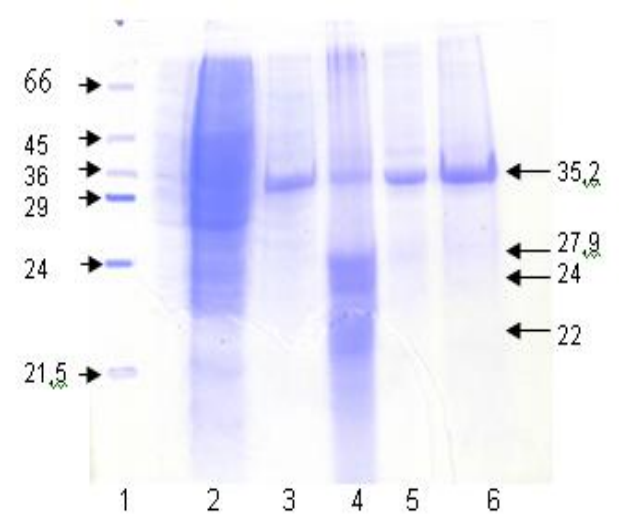

Gambar 1. Hasil SDS-PAGE whole cell dan potongan pili Proteus mirabilis

Keterangan :

Sumur 1: protein perunut

Sumur 2: whole cell

Sumur 3: potongan pili 1

Sumur 4: potongan pili 2

Sumur 5: potongan pili 3

Sumur 6: potongan pili 4

Tabel 2. Hasil uji hemaglutinasi protein pili dengan menggunakan eritrosit mencit

\begin{tabular}{lllllllllll}
\hline Berat \begin{tabular}{lllllll} 
protein \\
\cline { 2 - 9 }
\end{tabular} & 1 & 2 & 3 & 4 & 5 & 6 & 7 & 8 & 9 & 10 \\
\hline 35,2 & + & + & + & + & + & + & + & + & + & - \\
27,9 & + & + & + & - & - & - & - & - & - & - \\
24 & + & - & - & - & - & - & - & - & - & - \\
22 & + & - & - & - & - & - & - & - & - & - \\
\hline
\end{tabular}

Berdasarkan Tabel 2, dapat diketahui bahwa protein dengan berat molekul 35,2 kDa mempunyai titer tertinggi dan diduga merupakan protein hemaglutinin.

\section{Uji Adhesi}

Hasil uji adhesi Proteus mirabilis pada sel epitel vesika urinaria ditampilkan pada Gambar 2.

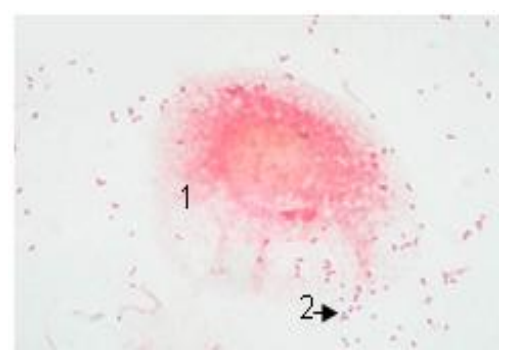

Gambar 2. Hasil uji adhesi Proteus mirabilis pada epitel vesika urinaria kelinci

Keterangan :

1. sel epitel vesika urinaria

2. Proteus mirabilis
Uji hambat adhesi dilakukan dengan menggunakan protein pili dengan berat molekul 35,2 $\mathrm{kDa}$. Protein dengan berat molekul 35,2 kDa ini dilakukan pengenceran secara bertingkat untuk menghambat adhesi Proteus mirabilis ke epitel vesika urinaria. Hasil uji hambat adhesi Proteus mirabilis pada epitel vesika urinaria adalah sebagai berikut (Gambar 3).

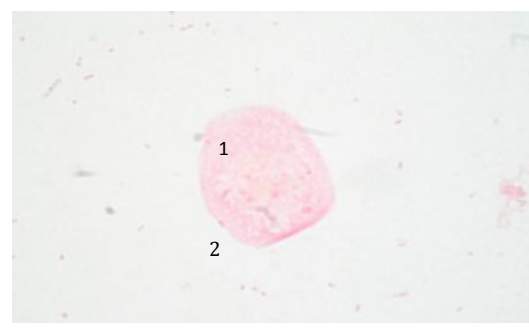

Gambar 3. Hasil uji hambat adhesi dengan konsentrasi $400 \mu \mathrm{l}$. Gambar direkam dengan foto mikroskop Olympus dengan perbesaran 1000 kali. Keterangan :

1. sel epitel vesika urinaria

2. Proteus mirabilis

Hasil uji adhesi dan uji hambat adhesi dianalisis dengan analisis varian satu jalur. Berdasarkan analisis varian satu jalur (One Way ANOVA) diketahui bahwa dosis pengenceran berpengaruh nyata terhadap indeks adhesi Proteus mirabilis ke sel epitel vesika urinaria kelinci dengan taraf signifikansi ( $p$ value) adalah 0,00 dengan tingkat kepercayaan $95 \%$.

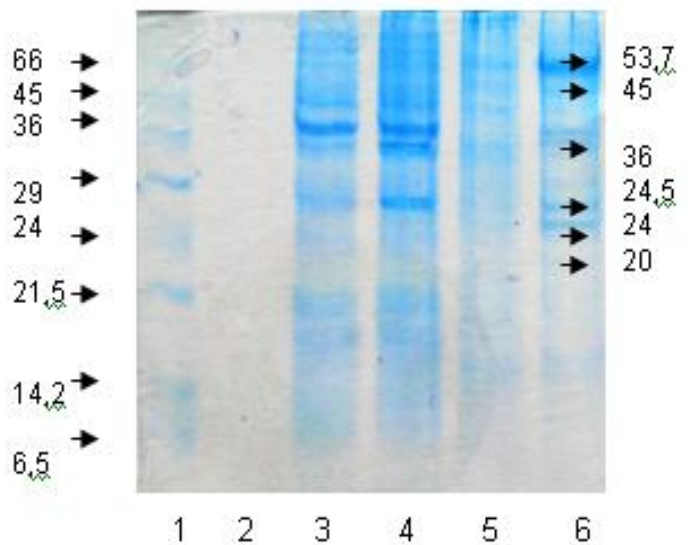

Gambar 4. Hasil SDS PAGE Matriks ekstraseluler yang telah disalut bakteri

Keterangan :

Sumur 1: protein perunut

Sumur 3: whole cell Proteus mirabilis

Sumur 4: pelet

Sumur 5: supernatan

Sumur 6: matrik ekstra seluler

\section{Uji Reseptor}

Hasil SDS PAGE untuk uji reseptor diperoleh data pada Gambar 4. Sumur ke-5 menggambar- 
kan matriks ekstraseluler, matriks mempunyai protein dengan berat molekul 53,7 kDa, $45 \mathrm{kDa}$, 36 kDa, 24,5 kDa, 24 kDa dan 20 kDa. Pelet dari bakteri yang disalut matriks ekstraseluler protein yang muncul dengan berat molekul $62 \mathrm{kDa}, 56,3$ kDa, 53,7 kDa, 45 kDa, 36 kDa, 35,8 kDa, dan 24,5 $\mathrm{kDa}$. Dari supernatan berat molekul yang didapat adalah 53,7 kDa, $45 \mathrm{kDa}$ dan $20 \mathrm{kDa}$. Protein yang tidak muncul di supernatan yaitu protein dengan berat molekul $36 \mathrm{kDa}, 24,5 \mathrm{kDa}$ dan $24 \mathrm{kDa}$.

Kemampuan pili dalam menggumpalkan sel darah merah ada dua tipe, yaitu Mannose Sensitive Hemaglutinin (MSHA) dan Mannose Resisten Hemaglutinin (MRHA). MRHA berubah menjadi MSHA apabila sel darah merah diberi asam tannat $0,01 \%$. Penelitian yang dilakukan oleh Sareneva, menunjukkan bahwa Proteus mirabilis mempunyai pili yang bersifat manosa resisten (MR/P) dengan berat molekul $21 \mathrm{kDa}$ [10].

Pada penelitian ini diperoleh protein hemaglutinin pili dengan berat molekul $22 \mathrm{kDa}$. Kemungkinan protein hemaglutinin dengan berat molekul $22 \mathrm{kDa}$ tersebut sama dengan MR/P yang ditemukan oleh Sareneva dengan berat molekul 21 kDa [10]. Namun hal tersebut perlu pembuktian lebih lanjut. Berdasarkan penelitian yang dilakukan oleh Rozalski terhadap bakteri Proteus mirabilis, juga diketahui bahwa bakteri tersebut mempunyai protein hemaglutinin pili, yang hanya mampu mengaglutinasi eritrosit, setelah diberi asam tannat, dan disebut dengan MR/K. Subunit pili ini mempunyai berat molekul $19,5 \mathrm{kDa}$ [11]. Sedangkan protein hemaglutinin dengan berat molekul 35,2 kDa, 27,9 kDa dan 24 $\mathrm{kDa}$, belum ada yang melaporkan.

Identifikasi adanya protein adhesi pili Proteus mirabilis pada sel epitel vesika urinaria, maka dilakukan uji adhesi dan hambat adhesi dengan menggunakan protein hemaglutinin dengan titer tertinggi, yaitu protein dengan berat molekul 35,2 kDa. Berdasarkan uji adhesi diperoleh hasil seperti pada Gambar 2. Berdasarkan gambar tersebut tampak adanya bakteri yang menempel pada sel epitel vesika urinaria dan ada beberapa bakteri yang sudah masuk ke sel epitel.

Sedangkan pada hambat adhesi dengan menggunakan protein hemaglutinin dengan berat molekul 35,2 kDa, tampak pada Gambar 3. Pada Gambar 3, dapat diketahui tidak ada bakteri yang melekat pada sel epitel, hal ini disebabkan oleh sebagian besar reseptor Proteus mirabilis telah dijenuhi oleh protein hemaglutinin pili, sehingga Proteus mirabilis P355 tidak dapat melakukan adhesi ke sel epitel. Ketika pengen- ceran protein hemaglutinin pili yang lebih besar maka reseptor yang dijenuhi oleh protein tersebut berkurang sehingga lebih banyak bakteri dapat menempel ke sel epitel. Semakin besar dosis protein yang diberikan menunjukkan semakin besar hambatan adhesi Proteus mirabilis P355 ke sel epitel dibandingkan dengan yang tanpa dihambat oleh protein hemaglutinin dengan nilai regresi $\left(r^{2}\right)=0,932$ dan $p$ value $=$ 0,000 .

Berdasar uji regresi tersebut menunjukkan bahwa terdapat hubungan yang signifikan antara protein pili dengan berat 35,2 kDa dengan indeks adhesi Proteus mirabilis P355 pada epitel vesika urinaria. Fenomena ini menunjukkan bahwa protein hemaglutinin pili Proteus mirabilis P355 dengan berat molekul 35,2 kDa merupakan protein adhesin.

Protein adhesi Proteus mirabilis dengan berat molekul 35,2 kDa belum ada yang melaporkan, oleh sebab itu perlu dilakukan penelitian lebih lanjut mengenai bentuk dari protein tersebut (monomer atau polimer), identifikasi gen penyandi dan $\mathrm{N}$-asam amino terminal. Sedangkan protein hemaglutinin dengan berat molekul 27,9 kDa, 24 kDa dan 22 kDa perlu dilakukan penelitian lebih lanjut, untuk mengetahui apakah protein tersebut merupakan protein adhesin.

Berdasarkan hasil SDS-PAGE (Gambar 4), yang bertujuan untuk mengetahui protein reseptor, dapat diketahui bahwa sumur ke-3 menggambarkan protein Proteus mirabilis P355 dengan berat molekul 61,8 kDa, 56,3 kDa, 43 kDa, 36 kDa, 35,3 kDa, 24 kDa, 21,5 kDa dan 15,4 kDa. Sumur ke-6 menggambarkan protein membran epitel vesika urinaria, protein tersebut mempunyai berat molekul 53,7 kDa, 45 kDa, 36 kDa, 35,3 kDa, 24,5 kDa dan 24 kDa.

Pelet dari bakteri yang disalut protein membran epitel yang muncul dengan berat molekul $62 \mathrm{kDa}, 56,3 \mathrm{kDa}, 53,7 \mathrm{kDa}, 45 \mathrm{kDa}, 36$ $\mathrm{kDa}$, 35,3 kDa, 24,5 kDa, 21,5 kDa dan 15,4 kDa (sumur ke-4, Gambar 4). Berat molekul yang didapat dari supernatan adalah 53,7 kDa dan 45 kDa. Protein yang tidak muncul di supernatan yaitu protein dengan berat molekul $36 \mathrm{kDa}, 35,3$ kDa, 24,5 kDa dan 24 kDa.

Berdasarkan hasil protein yang muncul pada tiap sumuran tersebut, dapat dianalisis dan diperkirakan bahwa molekul reseptor Proteus mirabilis P355 mempunyai berat molekul 36 kDa, 35,3 kDa 24,5 kDa dan 24 kDa. Hal ini terbukti pada supernatan tidak dijumpai protein dengan berat molekul tersebut, dan diperkirakan protein tersebut pindah ke sel bakteri. Kepastian protein 
tersebut sebagai molekul reseptor diperlukan penelitian lebih lanjut, yaitu dengan cara protein yang diprediksi sebagai molekul reseptor, dimurnikan dengan cara elusi dan eluat tersebut digunakan untuk uji hambat adhesi.

\section{KESIMPULAN DAN SARAN \\ Kesimpulan}

Proteus mirabilis P355 mempunyai protein hemaglutinin pili dengan berat molekul 35,2kDa, 27,9 kDa, $24 \mathrm{kDa}$ dan $22 \mathrm{kDa}$. Protein hemaglutinin pili Proteus mirabilis P355 dengan berat molekul 35,2 kDa mempunyai titer tertinggi $1 / 512$ merupakan protein adhesin. Proteus mirabilis P355 mempunyai protein reseptor di epitel vesika urinaria kelinci dengan prediksi berat molekul, 36 kDa, 35,3 kDa, 24,5 kDa dan 24 kDa.

\section{Saran}

Perlu penelitian lebih lanjut tentang tipe serta identifikasi $\mathrm{N}$-asam amino terminal protein hemaglutinin. Selain itu juga diperlukan penelitian lebih lanjut mengenai tipe dari protein adhesin dengan berat molekul 35,2 kDa dan menentukan bentuk protein pili tersebut merupakan suatu monomer atau polimer, serta mengidentifikasi gen penyandinya. Perlu pembuktian lebih lanjut protein reseptor dengan berat molekul $36 \mathrm{kDa}, 35,3 \mathrm{kDa}, 24,5 \mathrm{kDa}$ dan 24 kDa.

\section{DAFTAR PUSTAKA}

1. Gales, C.A., N.R. Jones, A.K. Gordon, S.H. Sader, W.W. Wilke, L.M. Beach, A.M. Pfaller, V.G. Doern. 2000. Activity and Spectrum of 22 Antimicrobial Agent Tested Againts Urinary Tract Infection Pathogens in Hospitalized patient in Latin America: report form the second year of the Sentry Antimicrobial Sueveillance Program. Journal of Antimicrobial Chemotherapy. 45:295-303.

2. Daifaku, Stamm. 1986. Bacterial Adherence to Bladder Uroepithelial Cells in catheterassoaiated Urinary Tract Infection. NEJM. 314:1208-1213.

3. Wassif, W.S., T.J. Peters. 1995. Familial isolated primary hyperparathyroidism. Clinical endocrino-logy. 42:441-442.

4. Salyers, A.A., D. Whitt. 1994. Bacterial Pathogenesis. ASM Press. Washington DC.

5. Sumarno. 2000. Karakterisasi Molekuler Protein Adhesi Vibrio cholerae 01 M094V dan Protein Reseptornya pada Sel Epitel Usus Halus Tikus Putih, Studi Patogenitas V. cholerae 01 M094V. Disertasi. Program Pascasarjana Universitas Airlangga. Surabaya.

6. Ehara, M., M. Ishibashi, Y. Ichinose, M. Iwanaga, S. Shimotori, T. Naito. 1987. Purification and Partial Characterization of Pili of Vibrio cholerae 01. Vaccine. 5:283-288.

7. Laemli, U.K. 1970. Cleavage of Structural Protein During Assembly of The Head of Bacteriophage T.4. Nature. 227:680-685.

8. Nagayama, K., T. Oguchi, M. Arita, T. Honda. 1995. Purification and characterization of a cell-associated hemagglutinin of Vibrio parahaemolyticus. Infection and Immunity. 05 1995. Vol 63. No. 5:1987-1992.

9. Li, X., H. Zhao, L. Geymonat, F. Bahrani, D.E. Johnson. 1997. Proteus mirabilis ManosaResistant, Proteus-Like Fimbriae:Mrp G is Located at the Fimbrial Tip and Is Required for Fimbrial Assembley. Infection and Immunity. 65:1327-1334.

10. Sareneva, T., H. Holtthofer, R.S. Cotran. 1990. Tissue binding affinity of Proteus mirabilis fimbriae in thr humn urinary tract. Infection and Immunity. 58:3330-3336.

11. Rozalski, A., Z. Sidorczyk, K. Kotelko. 1997. Poten-tial virulence factors of Proteus bacilli. Microbiol. Mol. Biol. Rev. Mar 1997. Vol 61. No. 1:65-89. 